\title{
From Brownfield to blue sky: Sydney Harbour's renaissance
}

\author{
S. Bargwanna \\ Kellogg Brown \& Root Pty Ltd, Sydney, Australia
}

\begin{abstract}
Sydney Harbour is one of the most magnificent in the world. It has some 230 kilometres of foreshores, is around 21 kilometres in length, one to two kilometres wide and up to 44 metres deep. It is the centre of Sydney, a metropolis of around four and half million people. The harbour was the reason for Sydney's settlement as a penal colony in 1788 and was the conduit for immigration and trade that developed over the ensuing 218 years.

This paper examines the circle of sustainability describing in four phases: the South Pacific utopia of Aboriginal occupation; the convict settlement - the city's foundation; the industrial-urbanisation period from the mid 1800 s to the early 1980s; and the current post industrial eco resort period.

Approaches to sustainability are discussed for each period using Cockatoo Island, the harbour's largest island as an example. The Aborigines lived a sustainable lifestyle. The subsequent convict settlement and urbanisation period had no concept of the consequences of social, economic and environmental impacts nor any awareness of the limits of growth. The current post-industrial eco resort period shows the harbour healing with a new awareness of sustainability and the use of the harbour as a playground rather than a sewer and shipping canal.

Lessons are offered from recent experiences in sustainable design and management principles in the harbour, many reflecting how the Aborigines experienced the harbour prior to European settlement. Use of such international natural feature icons as flagships for a global approach to sustainability is suggested.
\end{abstract}

Keywords: Sydney Harbour, sustainability, Cockatoo Island, urbanisation, postindustrial, eco resort. 


\section{Introduction}

Sydney Harbour was the location for the first European settlement in Australia, in January 1788, by Governor Arthur Phillip and his 11 ships of around 1000 convicts, soldiers and sailors. England had made a decision to establish a penal colony in Australia to relieve its overcrowded prisons. Sydney Harbour had a magnificent anchorage, capable of providing a safe haven for "over 1000 ships" or "the entire navies of Europe" as described by naval officers of the first fleet.

At the time, Sydney Harbour was populated by the Aboriginal Eora people, who led a relatively blissful and sustainable hunter-gather existence in harmony with nature. However, the brutal convict prison colony, with its "guns, germs and steel" [1], quickly destroyed Aboriginal society and ended its 60,000 year of lone occupation. The 230 kilometres of foreshores around Sydney Harbour and its tributaries were progressively urbanised and industrialised over the next 200 years, as far as the rugged sandstone topography allowed.

Today, Sydney is a prosperous multicultural city. The harbour has been a significant factor in Sydney's evolution into a 'second tier' world city, with a population of some four and a half million people. The driving forces behind this expansion were the global commercial export trade of wool, gold, wheat and other raw commodities and the import of people (and their material demands) from economic, war and religious mayhem-initially from Europe, then from Vietnam, the Middle East and elsewhere.

Sydney is also undergoing major economic and structural changes as it evolves from industrial to post-industrial, from provincial to global. The factories, utilities, refineries and uncontrolled urban waste systems that used the harbour as a free pollutant discharge sink have been progressively relocated and these sites rehabilitated over the past 20 years. The harbour has been rediscovered as a wonderful place to live, play and visit.

Tourism in Sydney was forecast to double from 4.2 million visitors in 1998 to 8.4 million in 2002 [2]. Global events such as the Olympic Games in 2000 and the annual New Year's Eve fireworks extravaganza have showcased the harbour and its metamorphosis to an international audience.

In this paper, the evolution of Sydney Harbour and approaches to sustainability will be described in four overlapping stages:

- the South Pacific utopian paradise

- the brutal convict prison settlement

- the industrial-urbanisation period

- the post industrial eco-resort.

To bring this broad sweep of Australia's history into sharper focus, this paper will also describe the ongoing transition of Cockatoo Island, the largest island in the harbour (17 hectares), as an example of the evolution of Sydney Harbour as a whole. This island has seen life as an Aboriginal fishing ground, a convict prison, a women's institution and a naval shipyard. It is now about to become a cultural and recreational 'must see' destination. Like the harbour, it's being cleaned up. The environmental qualities and spiritual significance of the island and the harbour, so well known to the indigenous inhabitants, are being 
rediscovered in a new future. Finally, the scope and opportunity to apply sustainability principles will be discussed and the hope that we can go a full circle in our treatment of the environment.

\section{The setting}

Sydney Harbour is the jewel of the Sydney metropolis. A drowned river valley, the harbour feeds from a $180^{\circ}$ catchment, effectively bifurcated by the South Pacific Ocean. The harbour and its tributaries contain some 230 kilometres of foreshores. These, when not modified by urban development, are typically rugged with many steep sandstone banks.

As Captain Arthur Phillip, the first Governor of the colony, described in 1788:

"it [the harbour] runs chiefly in a westerly direction about thirteen miles [21 kilometres] into the country, and contains not less than an hundred small coves, formed by narrow necks of land ... covered with timber, yet so rocky that it is not easy to comprehend how trees could have found sufficient nourishment..."

The width of the harbour is generally one to two kilometres. At its deepest point, near the Sydney Harbour Bridge - the narrowest harbour crossing point adjacent to the central business district-it is 44 metres to the bottom. Cockatoo Island, the largest in the harbour, is three kilometres west of the bridge and some 12 kilometres from The Heads (the 'gateway' to the open sea).

The harbour is a highly productive marine ecosystem, supporting many species of fish, prawns, shellfish (e.g. oysters and mussels) and seaweed as well as large marine creatures such as sharks, dolphins and whales-many over four metres long.

The foreshore comprises a diverse biology including intertidal mangrove, eucalypt and a variety of animals and birds.

Sydney has a Mediterranean type climate. It can experience violent weather-torrential rain, extreme heat, drought and bushfires.

\section{A South Pacific utopia}

For an estimated 60,000 years, Aboriginal people occupied Australia as huntergatherers, in relative isolation from other peoples and human migration waves. "Aborigines have the longest continuous cultural history of any group of people on earth".

At the time of the first European settlement in Sydney, in January 1788, there were an estimated 1500 Aboriginal people living around the harbour. These people did not cultivate the land and had no permanent settlements. They lived off, and in, nature. They fished sustainably with hooks, lines and multi-point spears, and derived sustenance and medicine from the natural landscape. The first English encounters found them a "very lively and inquisitive race" [3]. A district was named 'Manly' after the well built inhabitants. 


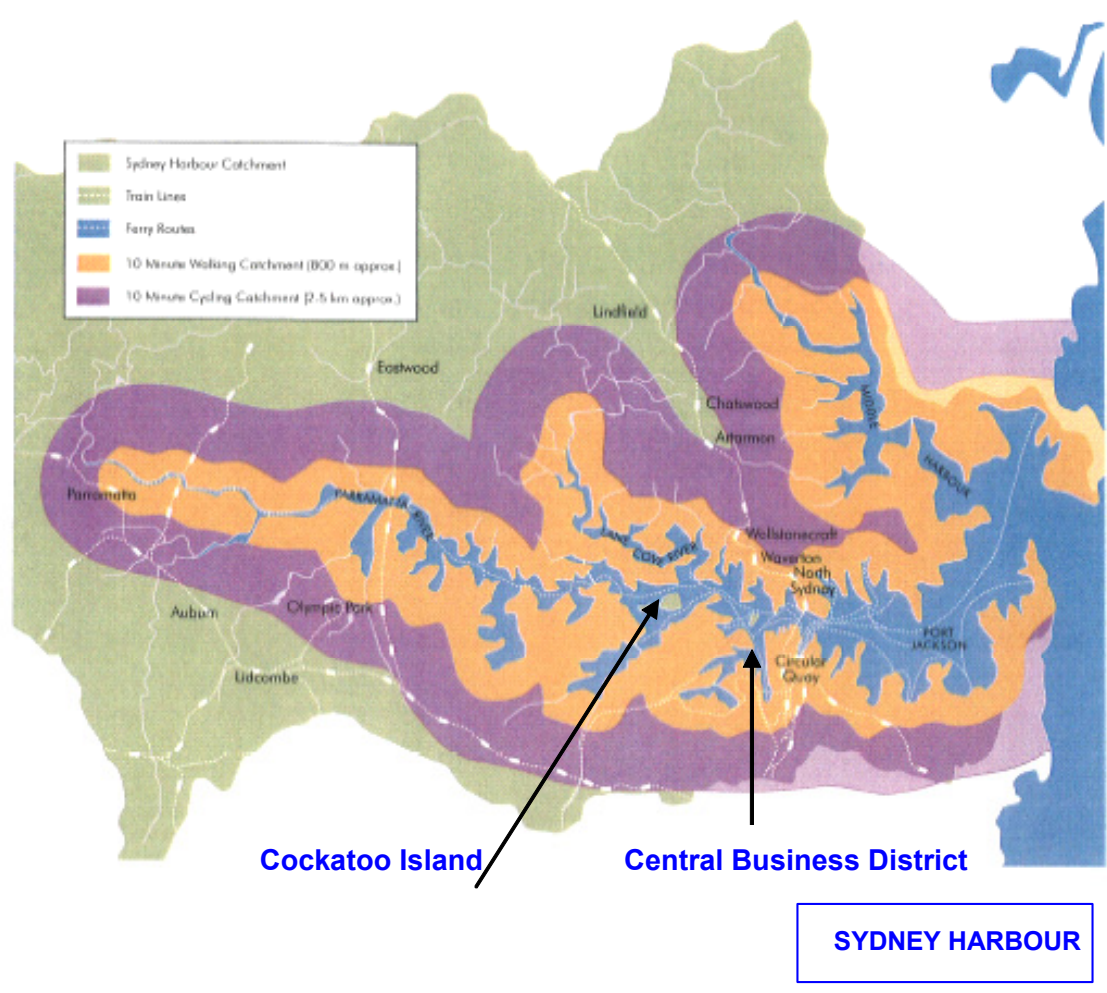

Source: Sharing Sydney Harbour Access Plan

Figure 1.

The Aborigines had to be environmentally sustainable; the earth was sacred, and they saw themselves as part of a metaphysical landscape and biological system. They lived according to their 'Dreamtime', which was a myriad of stories of how places were created.

"In the Aboriginal world view, every meaningful activity, event or life process that occurs at a particular place leaves behind a vibrational residue in the earth" [3].

Cockatoo Island was known to the local Aboriginal people as 'Wareamah' [4]. The island would have been a superb fishing and resting place. It is 200 metres to the north harbour shore and 1000 metres to the south harbour shore, and large (17 hectares). Its forest was habitat for the beautiful and striking white sulphur crested cockatoo, still prominent in Sydney. There were plenty of snakes, and the sandstone foreshores were bountiful in shellfish such as oysters, pippies and mussels. The many swimming holes would have provided variety and protection from prevailing winds.

The Eora, Ku-ring-gai, Darug and other peoples who inhabited Sydney Harbour before European settlement lived sustainably, in harmony with the harbour and its catchment. This existence may seem ancient, but it was not a 
long time ago in terms of human civilisation -218 years. Three, maybe four lifetimes. Ways in which Aborigines achieved a sustainable existence and low impacts on the harbour were in their nomadic lifestyle, fire regime, seed dispersal and selective hunting.

\section{Convict settlement: foundation of a city}

England had a number of problems that could, in part, be solved by establishing permanent settlements and occupation in Sydney and Australia. These included a large, poorly accommodated prison population (a consequence of urbanisation and industrialisation processes), the loss of the North American colonies and territorial rivalries with France.

The first fleet of 11 ships arrived in Sydney Harbour on 26 January 1788. It comprised more than 1000 convicts, sailors, marines and administrators together with food, provisions and animals to start the new settlement.

On arrival, the settlers recorded "the satisfaction of finding the finest harbour in the world, in which a thousand sail of the line may ride in the most perfect security" [5]. It could accommodate not only every British ship, but "for all the navies of Europe" [5].

At the time, this settlement-building expedition was a momentous achievement. Australia was seen as lying at the end of the earth; a land beyond the sea; the edge of oblivion. The settlers spent months at sea in cramped accommodation, continually buffeted by waves, fed dry biscuits and salt beef, anticipating death at any time. On arrival, there was "one mass outdoor party, Sydney's first fête of hedonism" [5]. One observer reported:

"It is beyond my abilities to give a just description of the scene of debauchery and riot which continued through the night" [5].

The settlers' first night on land coincided with a violent thunderstorm, which had no effects on the "wild drinking and orgy", but which was reportedly so violent that one lighting strike killed six sheep, two lambs and a pig.

The new convict colony was established first with tents, then wattle and daub, brick and finally cut sandstone. Permanent water supplies, tracks and foreshore works were established. However, the barren sandy soils would not support cultivation or grazing, and the early colony was placed on starvation rations. Ships were sent to South Africa, the South Pacific and Indonesia for food and other supplies. The native animals and vegetables were rejected as a food source - this was an alien land, in no way similar to Europe.

Finally, a fertile alluvial area was found on a harbour tributary, which supported the first successful crops and animal breeding.

More convict ships arrived, bringing prisoners who were urban dwellers, not farmers. Few had practical skills. Most were convicted of petty grievances (stealing bread and clothing); many were political criminals, like the Irish rebels. An iron discipline was maintained-convicts were regularly chained together and flogged, often by lashing whilst tied to a steel triangle. Serious offences led to hanging, with the body left on display as an example. Sydney's birth was a hard labour, known as by the 'convict stain', a history many would like to forget. 
The Aborigines also suffered badly, suddenly exposed to the systematic horrors of a penal system, and with no defence against foreign diseases from European city incubators. They were robbed of their fish and shellfish, infected with bacteria and viruses (from smallpox to syphilis), the woman raped and men murdered for theft.

Between 1788 and 1850, over 162,000 convicts were sent to Australia-many to Sydney.

Cockatoo Island was chosen as the site of a new convict establishment in 1839. It was to be a 'gaol within a gaol'; a place for repeat convict offenders who had originally been sent to Norfolk Island, off the coast of Sydney in the South Pacific. With Norfolk Island now full, Cockatoo Island was the next holding place for many recalcitrants.

By 1842 there were up to 500 convicts living in cramped congested conditions on Cockatoo Island. This band of prisoners undertook some magnificent civil projects, which are still evident today [4]:

- twenty grain storage silos were carved out of the island's sandstone, six metres deep and seven metres in diameter

- Sydney's iconic yellow block sandstone was quarried for public works in the growing city, including for the main harbour quay

- a drydock for shipbuilding and repair was constructed taking 10 years, it has been used for over 100 years to repair and build ships for the Navy and commerce

- the island's penal settlement infrastructure - wharves, gardens, water supply and transport—was largely built and run by convict labour.

The convict era provided the foundation for the development of Sydney, and the pastoral and mineral expansion throughout the colony of New South Wales. Sydney Harbour provided the conduit and catalyst for this development, and was seen as a limitless resource for fishing and transport. Its use for recreation was initially limited to a small class of administrators and merchants, but this would change.

Whist the English officers and administrators could admire the natural beauty of the harbour and the unique botany, there was no concept of sustainability. This was a harsh period focussed on survival of the new settlement with massive social impacts. The Aboriginal people were gradually disappearing. The environment was considered a limitless resource to be tamed and cultivated.

\section{The industrial-urbanisation period}

The industrial and urban expansion of Sydney occurred from around the mid 1800s. There were two dominant forces, both funnelled through the harbour: the immigration of free settlers from Europe and the United Kingdom (many escaping economic and political repression) and their need for manufactured goods; and the export of raw materials such as wool, wheat and gold.

The growth of the harbour's catchment was related to increased housing, while the city centre on the harbour flourished with commercial trade and 
administration. The harbour frontages, particularly around the quay and western bays, were characterised by docks, bond stores, warehouses and factories. Extensive land reclamation occurred.

The harbour became a busy transport artery, and as housing grew and factories developed, it also became a waste depository. The harbour received all the untreated liquid and solid waste of the growing town. The fresh water stream that provided the settlement's drinking water became so polluted and sedimented that new, distant water sources had to be found.

Progressively, industry established around the foreshore and ridgeswindmills, steam mills, flour mills, saw mills, foundries and abattoirs were built [6].

Extensive foreshore areas were reclaimed with dredging, piling and seawall construction. Some creeks entering the harbour were concrete lined. This period of growth was unhindered by any awareness of environmental sustainability.

In the $1900 \mathrm{~s}$, massive wheat silos were constructed, along with power stations that used the harbour's water for cooling and coal handling and petrochemical facilities. Long jetties were built into the harbour to facilitate the export of wool and other goods, and then for loading soldiers and their horses and chattels for war.

On Cockatoo Island, the convict prison complex was converted to an industrial school for girls, and a girls' reformatory was established. The island and moored ships also accommodated up to 500 homeless and orphaned boys, who were taught trades and nautical skills to be used in the burgeoning colony.

In response to the growing trade and the increasing size of the ships visiting Sydney Harbour, a second dry dock was built between 1882 and 1890 . Shipbuilding on the island began in 1870, largely for barges, dredges and tugs for the harbour and coastal development and trade. Naval ship building began in 1913.

During World War I, up to 4000 men were employed on Cockatoo Island in the varied and complex trades involved in shipbuilding. During World War II, the island became the main ship repair yard in the south-west Pacific, converting or repairing around 250 ships. This was the largest heavy industry site on the harbour and one of the most significant in Australia. During this period there was little or no awareness of environmental sustainability-concepts of external costs and limits to growth did not exist. The island and harbour were used for waste dumping. Consequently there was little or no consideration of the negative environmental, social or economic consequences of development.

\section{The post-industrial eco resort}

The beginning of the renaissance of Sydney Harbour as a sustainable ecosystem can be traced to the early 1980s. At this time, three major forces were at work.

First, in response to growing public awareness of the natural environment and the need for some protection, environmental legislation was enacted forcing industry and utilities to improve waste discharge and other practices. Second, Sydney was emerging as a global and regional commercial centre for tertiary industry such as finance, regional headquarters and information technology. At 
the same time, industry was modernising, often relocating to Asia or peripheral urban locations. Third, the Australian Government turned the eyes of the world on Australia and Sydney Harbour as a new tourist destination. The famous "throw another shrimp (prawn) on the barbie" campaign showcased Sydney and its harbour to an international audience for the first time.

The industrial and urban waterfront began to change rapidly, as people recognised the value of this natural feature; Sydneysiders now wanted to live and play by their harbour. To mark the bicentenary of Sydney's European settlement in 1988, the State Government developed two landmark catalyst rejuvenation harbour projects. The first saw the conversion of rail yards, wharves and a wholesale vegetable and meat district into an entertainment precinct with parks, cafés, themed shopping, convention and exhibition halls, a museum and Chinese garden. This precinct, known as Darling Harbour, launched a rejuvenation wave around the waterfront. The second was a major civic upgrade, at the original site of the First Fleet anchorage, crowned with the iconic Harbour Bridge and Opera House.

These projects precipitated urban and environmental renewal around the harbour. They fuelled dramatic growth in international and domestic tourism to Sydney, and created a demand for a new 'café harbour' society. The government also established the Sydney Harbour National Park, bringing together vast foreshore forests, beaches and islands.

The climax of this renaissance was the successful bid and execution of the Sydney Olympics in 2000. The focus on the Olympics was the remediation of a major harbour tributary site at Homebush Bay, which included an industrial waste dump, an abattoir and a brick pit.

The international showcasing of Sydney Harbour has since evolved to include an internationally renowned New Year's Eve fireworks display, adventure experiences such as the bridge climb, and harbour and international visiting ship cruises. Sydneysiders and the booming backpacker market now demand a clean harbour for such activities as kayaking, snorkelling, swimming and sailing. Numerous community groups work on harbourside revegetation and regular clean-up days. Sustainability has been re-discovered.

The harbour has become an eco-resort, a playground in the middle of a vast sprawling city.

There are still major remediation challenges. Recently, prawn harvesting in the harbour was suspended due to the discovery of dangerously high dioxin levels. This affected 20 commercial fishers, who had been a particularly attractive sight on the harbour.

Meanwhile, Cockatoo Island has undergone many positive and exciting changes. Shipbuilding has ceased and the island is being progressively rehabilitated, with great respect afforded to its convict, institutional and maritime heritage. Today plans are well developed to reinvent the island, this time as a 'must see' destination for tourism, maritime and culture-a Murano Island in Sydney. In 2005, the island hosted a very successful rock and roll festival! It is being rehabilitated to embrace sustainability. 


\section{Sydney Harbour Sustainable City Principles}

Sydney Harbour can be seen as going through a full circle as the modern postindustrial eco resort discovers principles of sustainability well known to the Aborigines but lost for some 200 years during the penal settlement and industrial-urbanisation period.

The harbour has been under intense pressure in the 218 years since European settlement. Fortunately, its sheer size and many rugged sections have kept it resilient and relatively healthy. However, to fix many of the poor practices of the past and to manage its ongoing sustainability amid the pressures of a dynamic changing city, there is much that we can - and are-doing. We have learned many "micro" lessons over the past twenty years on how to achieve a more sustainable harbour. Some of the principles I have learned from project experiences including at Cockatoo Island follow. Many of these are applicable to other harbour and waterway cities around the world.

- Education: the public, developers and practitioners need to be made aware of the harbour as a living four dimensional system. Waterways are more than mirror surface and static vista.

- Urban design: marine ecologists, not architects, should design foreshore edge treatments involving habitat creation, revegetation and cleansing. Edges should not be sterile.

- Construction: to encourage marine life, construct habitats such as artificial reefs, reduce velocity at foreshore edges through rubble treatments, use variegated rather than flat surfaces.

- Stormwater and sewers: pre-treat entering waters, use reeds, mangroves, ponds and natural filters.

- Land-use: create more parkland and wild edges with trails, have high value land uses (e.g. commercial buildings) pay for remediation.

- Decontamination: wherever possible, remove and treat; otherwise, cap and contain foreshore and marine sediments.

- Aboriginal interpretation: around the foreshore display and interpret Dreamtime stories and sustainable living practices. The convict penal story should also be told.

- Disaster and emergency response: regularly test capacity to respond to oil spills, accidents and terrorism.

- Events and festivals: use these as a focus of healing, celebration and awareness of the wonderful and essential sustainable asset that the harbour provides to the people and visitors to Sydney.

There are also major "macro" lessons for other world cities from considering the history and future of Sydney Harbour. What better way of showcasing sustainability to the domestic and international community than through the healing and rejuvenation of an international icon as a flagship for a global approach to sustainability. If the most visible natural treasures of a city can be managed sustainably there is hope that we can take this approach to other parts 
of the world. This can then help us to moderate our impacts so there is natural resource richness and diversity for future generations to enjoy.

\section{Acknowledgements}

Thanks for word processing, editing and reviewing to Juliet Fairley, Isabel Workman, David Abbey and Ana Naletilic of KBR-Sydney.

\section{References}

[1] Diamond J. Guns, Germs and Steel. Vintage 1998.

[2] Department Infrastructure, Planning and Natural Resources. Sharing Sydney Harbour Access Plan. August 2003.

[3] Australian Dreamtime. www.crystalinks.com.

[4] Sydney Harbour Federation Trust. The Story of Cockatoo Island. 2004.

[5] Kenneally T. The Commonwealth of Thieves. Random House 2005.

[6] Aplin G. and Storey J. Waterfront Sydney. 1860-1920. Unwin 1984.

[7] Birmingham J. Leviathan. Knopf, 1984. 